\title{
Ocean fifteen: new records of reef fish species in Hong Kong
}

Stanley K. H. Shea ${ }^{1,2^{*}}$ and Allen W. L. To $0^{2,3}$

\begin{abstract}
Background: This study reports 15 new reef fish species records for Hong Kong.

Methods: Studies were conducted from Jun to Oct in 2016 and 2017 and from Apr to Jul 2018, including 1841 man-hours of underwater visual surveys in day time using SCUBA in 54 sites in Hong Kong.

Results: The validity of these 15 records, whether these fish might have been artificially released or naturally occurring, is discussed and this study confirms the natural presence of these 15 species in Hong Kong.

Conclusions: Results from this study is fundamental to enhance understanding and documentation of Hong Kong's reef fishes, also to serve as key information during the action and planning of the implementation of Biodiversity Strategy and Action Plan for Hong Kong.
\end{abstract}

Keywords: Hong Kong, Reef fish, New records, Acanthuridae, Apogonidae, Blennidae, Gobiesocidae, Gobiidae, Holocentridae, Muraenidae, Pomacentridae, Serranidae

\section{Background}

Hong Kong Special Administrative Region of the People's Republic of China lies at the northern limits of the tropics between latitudes $22^{\circ} 08^{\prime} \mathrm{N}$ and $22^{\circ} 35^{\prime} \mathrm{N}$ and longitudes $113^{\circ} 49^{\prime} \mathrm{E}$ and $114^{\circ} 31^{\prime} \mathrm{E}$. Located on the Pearl River Delta and within the South China Sea, Hong Kong has more than 200 offshore islands and approximately $1650 \mathrm{~km}^{2}$ of territorial waters (hk-fish.net 2018). Although Hong Kong's territorial waters make up only about $0.03 \%$ of the China sea area, it is recently reported as home to almost 6000 marine species, accounting for about $26 \%$ of the total marine species records in China (Ng et al. 2017).

Hong Kong's waters are also known to house a diversity of fish species comparable to the entire Caribbean Sea (Sadovy 2001). This is evidenced by approximately 1000 fish species that were documented by hk-fish.net (2018). Despite being a home to such an enormous array of marine life, efforts to document the diversity of species residing in these reefs through research and

\footnotetext{
* Correspondence: stanleyshea@bloomassociation.org

'BLOOM Association, C/o, ADMCF, Suite 2405, 9 Queen's Road Central,

Victoria, Hong Kong

${ }^{2} 114^{\circ} \mathrm{E}$ Hong Kong Reef Fish Survey, c/o, ADMCF, Suite 2405, 9 Queen's Road

Central, Victoria, Hong Kong

Full list of author information is available at the end of the article
}

monitoring, however, are still relatively scarce, spontaneous and dispersed. A study by Sadovy and Cornish (2000) estimated that over 500 species of reef fish might eventually be found in Hong Kong's waters but their research recorded 325 species at that time. More recent studies and publications reported additional reef fish species to Hong Kong, boosting the number to over 340 reef fish species (To et al. 2013; To and Shea 2016).

In response to the United Nation's Convention on Biological Diversity (CBD), the People's Republic of China, which became one of the 196 signatories and Parties in 1992 (signed) and 1993 (ratified Party) (CBD 2018), announced its first national Biodiversity Strategy and Action Plan (BSAP) in 1994, which was updated in 2010. This commitment was extended to the Hong Kong Special Administrative Region in 2011, and Hong Kong came to create the first city-level BSAP. The BSAP is a strategic instrument aimed at addressing threats to biodiversity, identifying priorities, setting strategies and outlining actions for supporting biodiversity conservation, and assisting Hong Kong in meeting Aichi Biodiversity Targets through implementable actions at the local level, thus contributing to efforts implementing the CBD (Environment Bureau 2016).

(c) The Author(s). 2018 Open Access This article is distributed under the terms of the Creative Commons Attribution 4.0 International License (http://creativecommons.org/licenses/by/4.0/), which permits unrestricted use, distribution, and reproduction in any medium, provided you give appropriate credit to the original author(s) and the source, provide a link to the Creative Commons license, and indicate if changes were made. The Creative Commons Public Domain Dedication waiver (http://creativecommons.org/publicdomain/zero/1.0/) applies to the data made available in this article, unless otherwise stated. 
Understanding the diversity of the species we have in our environment is fundamental to the evaluation, protection and conservation of biodiversity. With existing data collection efforts and analyses being scarce and dispersed, it is difficult to monitor marine resources (Cotterill 1995; De Lacy et al. 2006) and devise management plans. The BSAP under the CBD therefore provides a unique opportunity for Hong Kong to bridge the gaps in the existing knowledge of local reef fishes through updating the reef fish species inventory for Hong Kong and collecting foundational information on reef fish species diversity according to geographical distribution. The species presented in this paper are findings arising from a continuing study, which aims to form the basis of an on-going documentation on Hong Kong reef fish diversity, and to provide such vital information to the formulation of action and plans arising from Hong Kong's BSAP.

\section{Methods}

Between Jun and Oct in 2016 and 2017, and from Apr to Jul 2018, a total of 1841 man-hours of underwater visual surveys using SCUBA were conducted in at least 54 sites in Hong Kong, mainly in daytime. The seasonality of the surveys ensures maximum activity of reef fishes in sub-tropical Hong Kong (Cornish 1999). These surveys were conducted by a total of 128 divers who have varying degrees of fish identification experience. All surveys were led by at least one of the authors but most surveys involved both.

All new species were observed underwater and specific behavior and interaction with other marine life were noted. Photographs were taken to verify identification of all new species to Hong Kong. Species identities were further verified by experts outside Hong Kong who have extensive experience in reef fish research. The approximate GPS location of the new species records were retrieved using Google Earth (Fig. 1).

\section{Results}

A total of 15 new reef fish species to Hong Kong were recorded in these surveys, and these comprise nine families, namely Blennidae (3 species), Apogonidae (2 species), Gobiidae (2 species), Holocentridae (2 species),

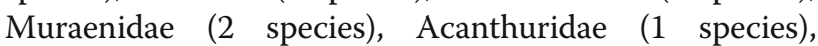
Gobiesocidae (1 species), Pomacentridae (1 species) and Serranidae (1 species). New species to Hong Kong were regarded as those which have neither been documented on hk-fish.net (2018) - a government maintained marine fish database of Hong Kong, or in earlier reef fish studies in Hong Kong (Ni and Kwok 1999; Sadovy and Cornish 2000; To et al. 2013; To and Shea 2016).
Chromis fumea (Tanaka, 1917) family: Pomacentridae An individual of Chromis fumea (Tanaka, 1917) (Fig. 2) was spotted swimming among a school of Chromis notata (Temminck \& Schlegel 1843) in the water column above boulders at about $8 \mathrm{~m}$ in depth at Ping Min Chau $\left(22^{\circ} 18^{\prime} 41^{\prime \prime} \mathrm{N}, 114^{\circ} 19^{\prime} 04^{\prime \prime} \mathrm{E}\right)$ on 10 th July 2016 , in day time. The individual was about $5 \mathrm{~cm}$ in total length. Individuals of Chromis fumea were since observed several more times around Hong Kong, also swimming among schools of Chromis notata. As Chromis notata is one of the most common reef fish species in Hong Kong, and their appearance and behavior are very similar to Chromis fumea (To and Shea 2017), it is possible that previous occurrences of Chromis fumea were missed by divers. The native range of Chromis fumea covers the Indo-West Pacific, mainly the western Pacific region, including Australia, Indonesia, Japan, South Korea, Lord Howe Islands, Malaysia, mainland China, New Caledonia, New Zealand, Norfolk Islands, Ryukyu Islands, Taiwan and Vietnam (Fishbase 2018a; Liu 2008; Wu 2012;)

\section{Pherallodus indicus (Weber, 1913) family: Gobiesocidae}

An individual of Pherallodus indicus (Weber, 1913) (Fig. 3), about $2 \mathrm{~cm}$ in total length, was spotted and photographed at Tai Hang Tun $\left(22^{\circ} 17^{\prime} 28^{\prime \prime} \mathrm{N}, 114^{\circ} 18^{\prime} 22^{\prime \prime}\right.$ E) at around $2 \mathrm{~m}$ in depth on $27 \mathrm{Jul} 2016$ in day time. The location was exposed to strong wave action and barnacles and sea urchins were commonly found along that rocky shore. The clingfish was first found lying on the rock surface near a sea urchin. As the surveyor approached, the clingfish hid beneath the sea urchin and when the sea urchin started to move, the clingfish moved alongside it. Pherallodus indicus is naturally found in the Western Central Pacific region, and has been reported from Indonesia, Japan, Lord Howe Islands, mainland China, New Caledonia, Pitcairn, Taiwan, Tonga and Tuamotu Islands (Fishbase 2018b; Liu 2008; Wu 2012).

\section{Petroscirtes springeri Smith-Vaniz, 1976 family: Blennidae} Two individuals of Petroscirtes springeri Smith-Vaniz, 1976 (Fig. 4) and subsequently four individuals of this species were spotted on 16 Sept and 29 Oct 2016 respectively at Basalt Island $\left(22^{\circ} 18^{\prime} 31^{\prime \prime} \mathrm{N} ; 114^{\circ} 21^{\prime} 52^{\prime \prime} \mathrm{E}\right)$ in day time. All these observations involved individuals of Petroscirtes springeri at about $7 \mathrm{~cm}$ in total length and were made at Basalt Island at about $16-18 \mathrm{~m}$ in depth. The location was a rocky reef and the habitat where Petroscirtes springeri were observed was a mix of boulder, rubble and sand with occasional small gorgonian. These individuals of Petroscirtes springeri were observed to hover above the seabed in a noticeably more static manner than another commonly observed blenny 


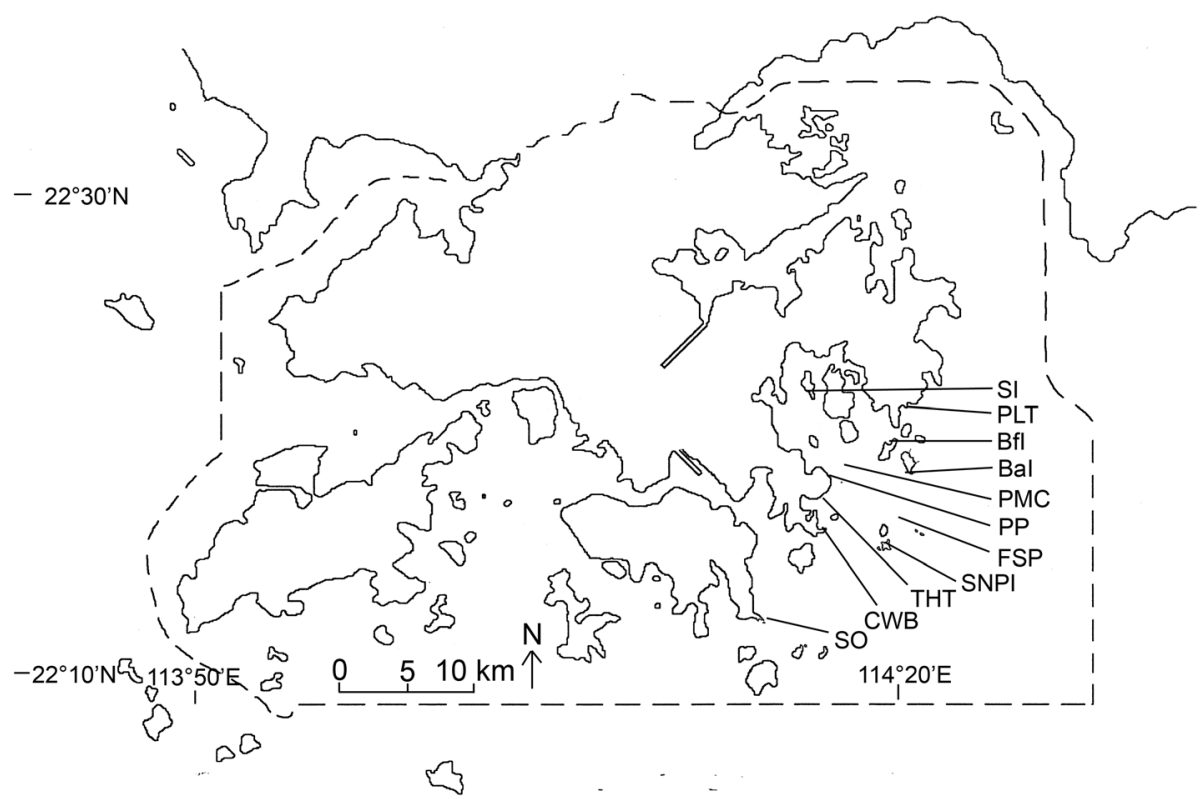

Fig. 1 Locations of the observed new reef fish species, Pak Lap Tsai (PLT), Sharp Island (SI), Bluff Island (BfI), Basalt Island (Bal), Pak Pai (PP), Ping Min Chau (PMC), Fo Siu Pai (FSP), South Ninepin Islands (SNPI), Tai Hang Tun (THT), Clearwater Bay (CWB) and Shek O (SO)

species Petroscirtes breviceps, which tends to be in contact with the substrate or moving actively over it. Petroscirtes springeri is found in the northwest Pacific, including mainland China, Japan and Taiwan, (Fishbase 2018c; Liu 2008; Wu 2012).

\section{Myripristis botche Cuvier, 1829 family: Holocentridae}

A single individual of Myripristis botche Cuvier, 1829 was spotted hovering around a dead coral in the middle of a sandy bottom habitat at around $10 \mathrm{~m}$ in depth during day time on 18 Sep 2016, at South Ninepin Islands $\left(22^{\circ} 15^{\prime} 33^{\prime \prime} \mathrm{N}\right.$; $\left.114^{\circ} 20^{\prime} 57^{\prime \prime} \mathrm{E}\right)$ (Fig. 5). This soldierfish individual, estimated to be around $20 \mathrm{~cm}$ in total length, was observed to remain at the same dead coral for over an hour but would immediately retreat into the dead

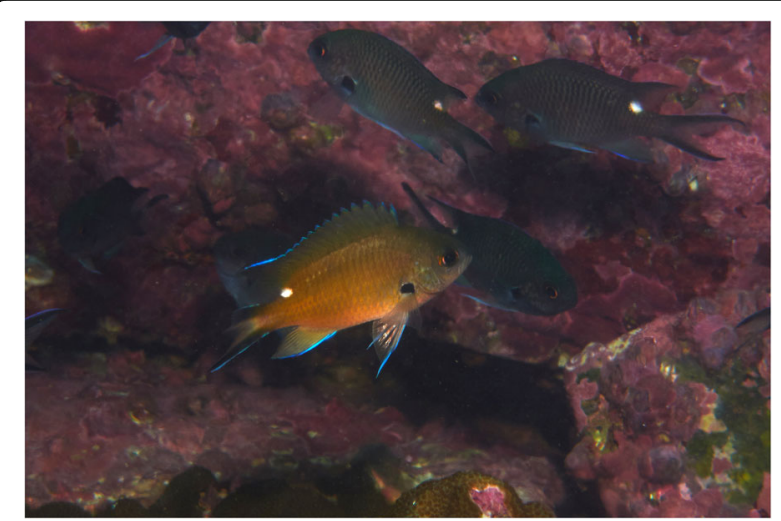

Fig. 2 An individual of Chromis fumea among a school of Chromis notata observed at Ping Min Chau coral when a torch was used to point to the fish. This species is naturally found in the Indo-West Pacific, including Australia, Brunei Darsm, India, Indonesia, Japan, South Korea, mainland China, Malaysia, Maldives, Mauritius, Mayotte, Mozambique, New Caledonia, Ogasawara Islands, Philippines, Ryukyu Islands, Seychelles, Somalia, South Africa, Sri Lanka, Taiwan, Thailand, Vanuata and Vietnam (Fishbase 2018d; Liu 2008; Wu 2012).

\section{Valenciennea wardii (Playfair, 1867) family: Gobiidae}

An individual of Valenciennea wardii (Playfair, 1867) was recorded on 19 Sep 2016 at South Ninepin Islands $\left(22^{\circ} 15^{\prime} 33^{\prime \prime} \mathrm{N}\right.$; $114^{\circ} 20^{\prime} 57^{\prime \prime} \mathrm{E}$ ) (Fig. 6), at about $8 \mathrm{~m}$ in depth in day time. The goby was observed to be wary of

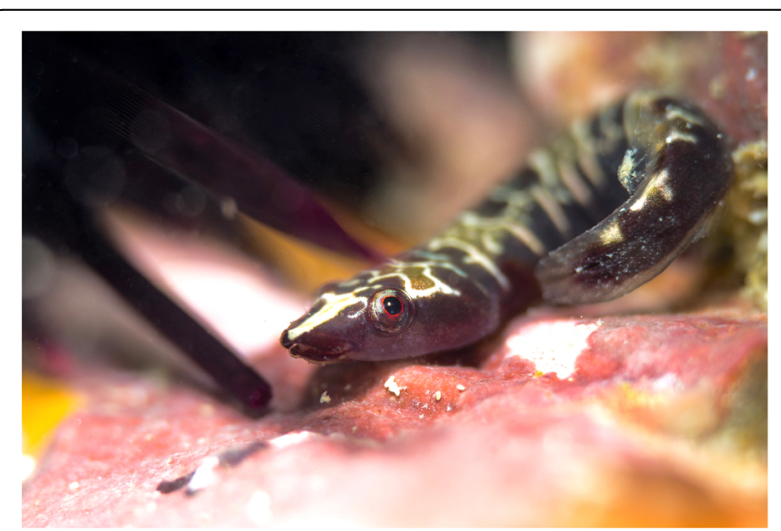

Fig. 3 An individual of Pherallodus indicus observed at Tai Hang Tun in shallow water at the rocky shore 


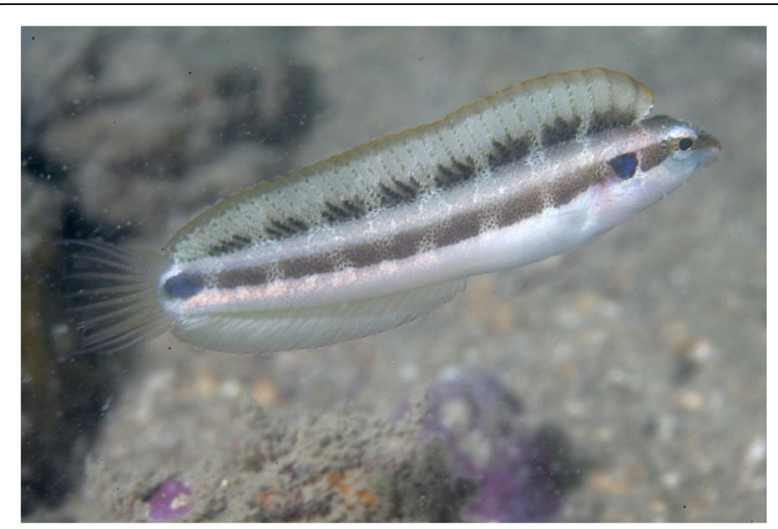

Fig. 4 An individual of Petroscirtes springeri recorded at Basalt Island over a mix of boulder, rubble and sand habitat

the surveyor and maintained a distance from the surveyor by moving around over the sandy and muddy bottom. The goby individual was estimated to be around $11 \mathrm{~cm}$ in total length. This species is found in the Indo-Pacific, including Andaman Islands, Australia, Indonesia, Japan, mainland China, Maldives, Papua New Guinea, Philippines, Seychelles, Sudan, Taiwan, Tanzania, Thailand and Vietnam (Fishbase 2018e; Liu 2008; Wu 2012).

Myripristis hexagona (Lacepède, 1802) family: Holocentridae A single individual of Myripristis hexagona (Lacepède, 1802) was observed swimming around boulders at a rocky reef at night, at Basalt Island $\left(22^{\circ} 18^{\prime} 31^{\prime \prime} \mathrm{N} ; 114^{\circ} 21^{\prime}\right.$ 49"E) (Fig. 7), on 24 Sep 2016. The soliderfish individual was around $20 \mathrm{~cm}$ in total length and was found at about $15 \mathrm{~m}$ in depth. Myripristis hexagona is distributed in the Indo-Pacific, and found in around 35 countries or territories including Indonesia, Japan, mainland China, Malaysia, Ogasawara Islands, Philippines, Ryukyu Islands, and Taiwan (Fishbase 2018f; Liu 2008; Wu 2012).

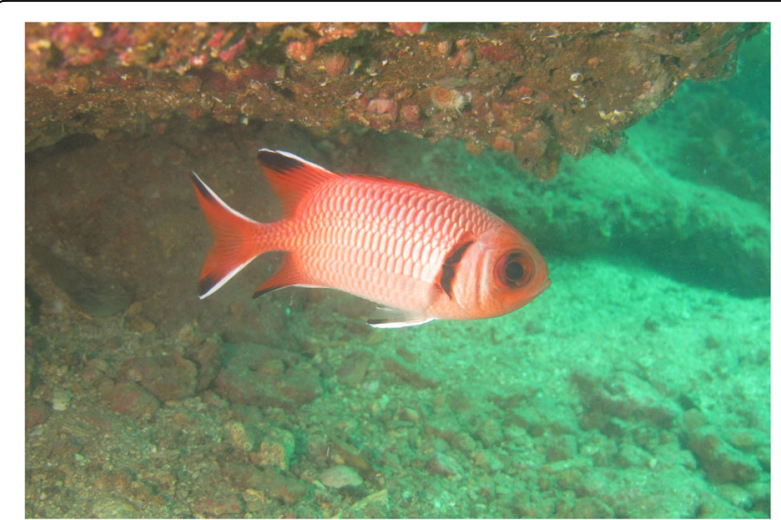

Fig. 5 An individual of Myripristis botche observed to hover around a dead coral at South Ninepin Islands

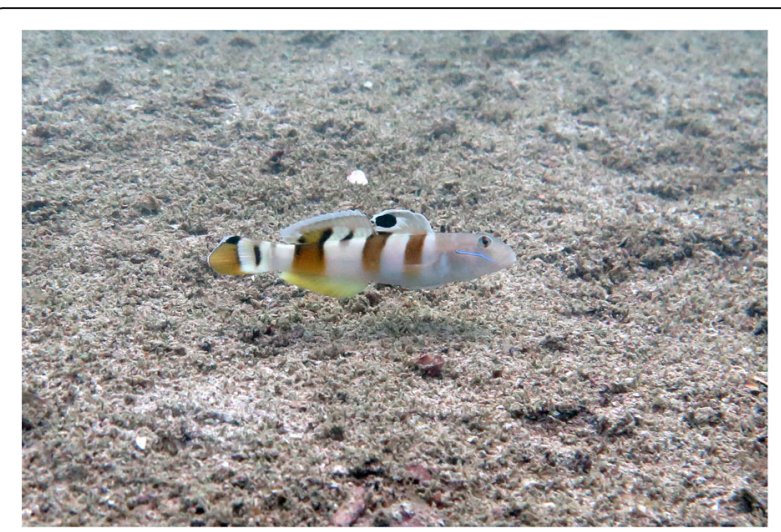

Fig. 6 An individual of Valenciennea wardii recorded at South Ninepin Islands over sandy muddy bottom

\section{Pseudanthias squamipinnis (Peters, 1855) family: Serranidae}

Four individuals of Pseudanthias squamipinnis (Peters, $1855)$ were observed at Fo Siu Pai $\left(22^{\circ} 16^{\prime} 33^{\prime \prime} \mathrm{N} ; 114^{\circ} 21^{\prime}\right.$ $35^{\prime \prime} \mathrm{E}$ ) in day time on 10 Jun 2017, at around $16 \mathrm{~m}$ in depth (Fig. 8). These four individuals were observed among a school of Chromis notata (Temminck \& Schlegel, 1843), hovering around boulders where barnacles and soft corals abound. This school of anthias and damselfish were seen to actively feed on micro-organisms brought in by the current at that location. The anthias individuals were alert of surveyors and were seen to retreat into rock crevices or hide among spines of sea urchins. This species is distributed in the Indo-West Pacific and found in about 39 countries or territories including Indonesia, Japan, South Korea, mainland China, Ogasawara Islands, Philippines, and Taiwan (Fishbase 2018g; Liu 2008; Wu 2012).

\section{Xiphasia setifer Swainson, 1839 family: Blennidae}

An individual of Xiphasia setifer Swainson, 1839 was observed on 3 Jun 2017 in day time at about $8 \mathrm{~m}$ in depth,

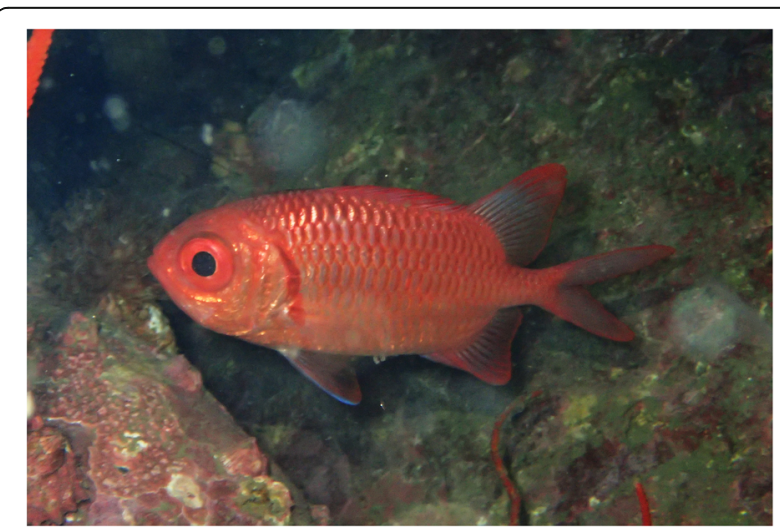

Fig. 7 An individual of Myripristis hexagona observed swimming around boulders at night at Basalt Island 


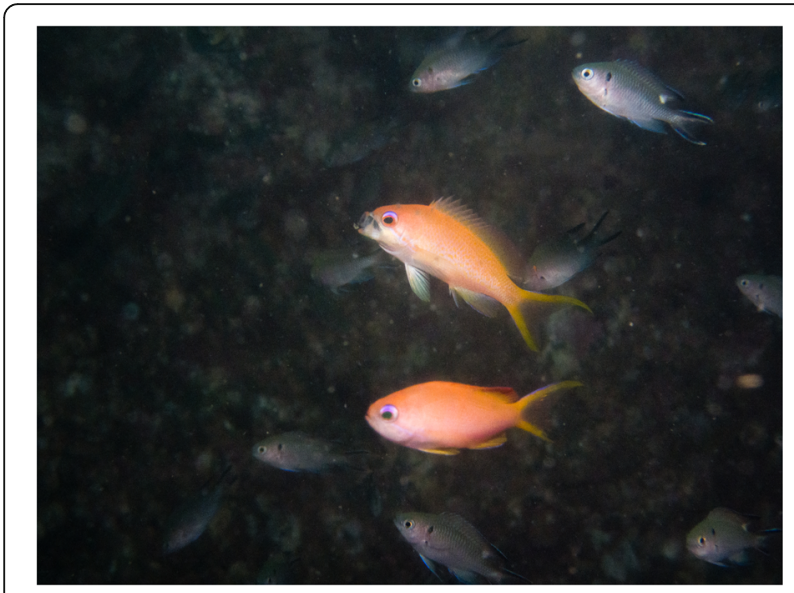

Fig. 8 Individuals of Pseudanthias squamipinnis observed at Fo Siu Pai, hovering around boulders

over sandy to muddy bottoms off rocky areas at Bluff Island $\left(22^{\circ} 19^{\prime} 27^{\prime \prime} \mathrm{N} ; 114^{\circ} 21^{\prime} 09^{\prime \prime} \mathrm{E}\right)$ (Fig. 9). This blenny was observed to occupy a burrow close to an individual of a bandfish species (Acanthocepola sp.). The blenny stayed mostly within the burrow but occasionally came out to expose part of the body outside the burrow. The total length of the blenny therefore could not be estimated but the exposed body part was about $40 \mathrm{~cm}$ in length. The same species, likely the same individual, was spotted again near the same area and habitat on 16 Jun 2017. Xiphasia setifer is found in the Indo-West Pacific, including Andaman Islands, Australia, Bahrain, India, Indonesia, Japan, Kuwait, Lord Howe Islands, Madagascar, mainland China, Malaysia, Mauritius, New Caledonia, Oman, Papua New Guinea, Philippines, Qatar, Saudi Arabia, South Africa, Taiwan, Thailand, UAE and Vanuata (Fishbase 2018h; Liu 2008; Wu 2012).

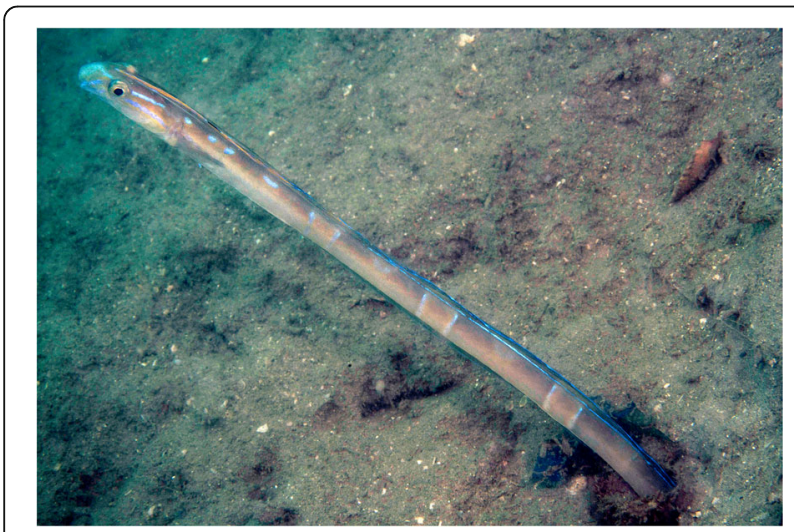

Fig. 9 An individual of Xiphasia setifer observed occupying a burrow over sandy to muddy bottoms off rocky areas at Bluff Island

\section{Cheilodipterus species family: Apogonidae}

An individual of a Cheilodipterus species was observed and photographed at Clearwater Bay $\left(22^{\circ} 16^{\prime} 19^{\prime \prime} \mathrm{N} ; 114^{\circ}\right.$ $18^{\prime} 07^{\prime \prime}$ ) (Fig. 10), on 29 Jul 2017 in day time. The observed individual was about $10 \mathrm{~cm}$ in total length, found to be hiding near rocky reefs and occasionally swam along the margin of the reef adjacent to the sandy bottom, at about $7 \mathrm{~m}$ in depth. The individual was observed to occasionally mix into a group of about 10 similarly-sized Ostorhinchus fleurieu Lacepède, 1802. Based on the photograph, the whitish tail base and the brown stripes being generally thicker than the whitish interspaces on the body indicate the individual being either Cheilodipterus intermedius (Gon, 1993) or Cheilodipterus macrodon (Lacepède, 1802) (Allen and Erdmann 2012; Allen et al. 2015). Cheilodipterus intermedius is similar to Cheilodipterus macrodon, but the former is generally slenderer in shape and has a more pronounced whitish area on caudal fin base without a hint of black bar (Allen and Erdmann 2012; Allen et al. 2015). While it is challenging to accurately identify the individual based on the single observation and photographs taken, either of the speculated species would be a new record for Hong Kong, where Cheilodipterus artus (Smith, 1961) is the only Cheilodipterus species recorded so far (hk-fish.net 2018; Sadovy and Cornish 2000; To et al. 2013; To and Shea 2016). While Cheilodipterus macrodon is more widespread and found in about 55 countries or territories in the Indo-Pacific from Red Sea and East Africa to Pitcairn, north to the Ryukyu Islands, south to Lord Howe Islands and Rapa (Fishbase 2018i; Liu 2008; Wu 2012), Cheilodipterus intermedius is relatively more restricted and is reported from around 10 countries or territories in the Western Pacific from Japan south to Australia east to Solomon Islands (Fishbase 2018; Liu 2008; Wu 2012).

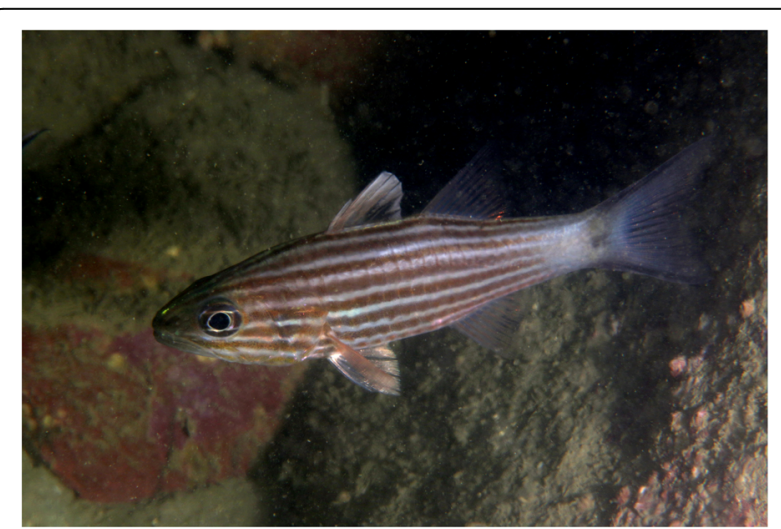

Fig. 10 An individual of Cheilodipterus species observed at Clearwater Bay near a rocky reef 


\section{Aspidontus taeniatus Quoy \& Gaimard, 1834 family:} Blennidae

An individual of Aspidontus taeniatus Quoy \& Gaimard, 1834 was recorded at Pak Pai $\left(22^{\circ} 18^{\prime} 25^{\prime \prime} \mathrm{N}\right.$; $114^{\circ} 18^{\prime} 21^{\prime \prime}$ E) on 20 Aug 2017 in day time (Fig. 11). The blenny individual was about $10 \mathrm{~cm}$ in total length and was seen swimming around boulder and rubble habitats at around $5 \mathrm{~m}$ in depth. This blenny was noted to swim alongside an individual of Labroides dimidiatus (Valenciennes, 1839), which the blenny mimics in body colour, pattern and even movement (Kuwamura 1983). Aspidontus taeniatus is found in the Pacific Ocean covering about 31 countries and territories including Australia, Indonesia, Japan, mainland China, Philippines and Taiwan (Fishbase 2018k; Liu 2008; Wu 2012).

\section{Tomiyamichthys oni (Tomiyama, 1936) family: Gobiidae} A single individual of Tomiyamichthys oni (Tomiyama, 1936) was found in rubble habitats at depths of about $15 \mathrm{~m}$ (Fig. 12), in southern waters $\left(22^{\circ} 12^{\prime} 20^{\prime \prime} \mathrm{N} ; 114^{\circ} 15^{\prime}\right.$ $\left.38^{\prime \prime} \mathrm{E}\right)$ adjacent to Shek O on 30 Apr 2018 in day time. The goby, which was about $10 \mathrm{~cm}$ in total length, was alert of surveyors and stayed close to the entrance to a burrow, and the goby immediately retreated into the burrow when the surveyor approached. This species is found in the Western Pacific including Indonesia, Japan, mainland China, Malaysia, New Caledonia, Ogasawara Islands, Palau, Papua New Guinea, Ryukyu Islands and Taiwan (Fishbase 2018l; Liu 2008; Wu 2012; Shao 2018).

Gymnothorax albimarginatus (Temminck \& Schlegel, 1846) family: Muraenidae

An individual of Gymnothorax albimarginatus (Temminck \& Schlegel, 1846) (Fig. 13) was spotted in day time near the edge of the rocky reef at Sharp Island $\left(22^{\circ} 21^{\prime} 39^{\prime \prime} \mathrm{N}, 114^{\circ} 17^{\prime} 28^{\prime \prime} \mathrm{E}\right)$, at about $10 \mathrm{~m}$ in depth. The individual was estimated to be about

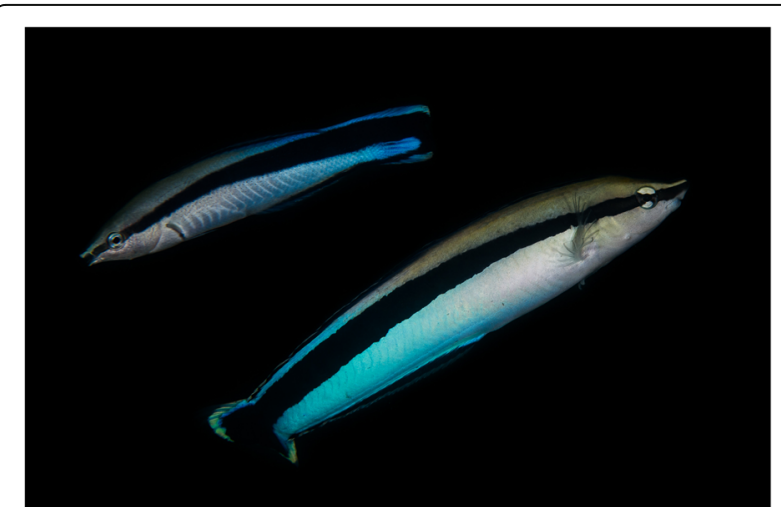

Fig. 11 An individual of Aspidontus taeniatus at the front and Labroides dimidiatus at the back, at Pak Pai around boulder and rubble habitat

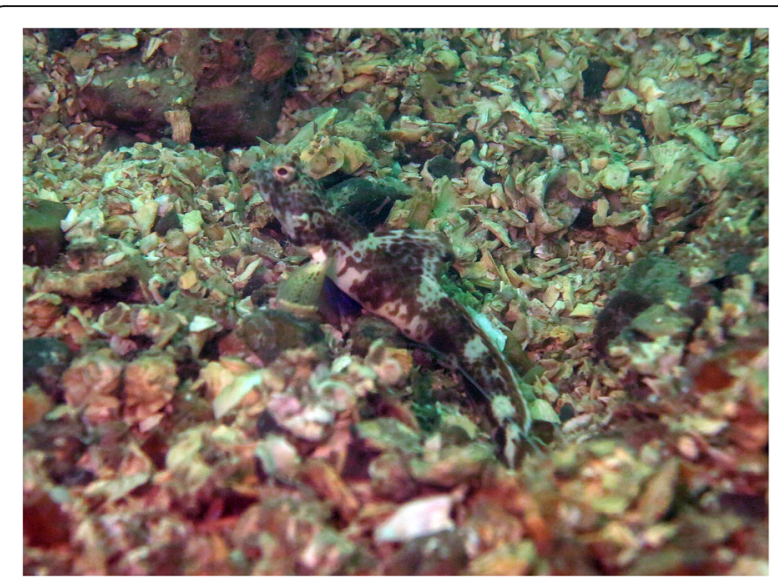

Fig. 12 An individual of Tomiyamichthys oni observed in southern waters adjacent to Shek $O$ in rubble habitat

$60 \mathrm{~cm}$ in total length and was observed to rest with the body curved over the sandy bottom. It then swam around, apparently to look for shelter. The species is found in the Indo-Pacific, including Indonesia, Japan, South Korea, mainland China, New Caledonia, Samoa and Taiwan (Fishbase 2018m; Liu 2008; Wu 2012).

\section{Rhabdamia gracilis (Bleeker, 1856) family: Apogonidae}

Two individuals of Rhabdamia gracilis (Bleeker, 1856) were observed swimming towards the light source of the divers during a night dive at Clearwater Bay $\left(22^{\circ} 16^{\prime}\right.$ $19^{\prime \prime N}$; 114 $18^{\prime} 07^{\prime \prime} \mathrm{E}$ ) on $1 \mathrm{Jul} 2018$ (Fig. 14). The two individuals were observed to swim closely to each other over rocky substrate, at about $5 \mathrm{~m}$ in depth. Both individuals were estimated to be about $5 \mathrm{~cm}$ in total length. This species is found in the Indo-West Pacific, including Mauritius, Mozambique, Seychelles, South Africa, Tanzania, Andaman Islands, Cocos Islands, India, Indonesia, Japan, mainland China, Malaysia, Maldives, Philippines, Ryukyu Islands, Taiwan, Vietnam, Australia,

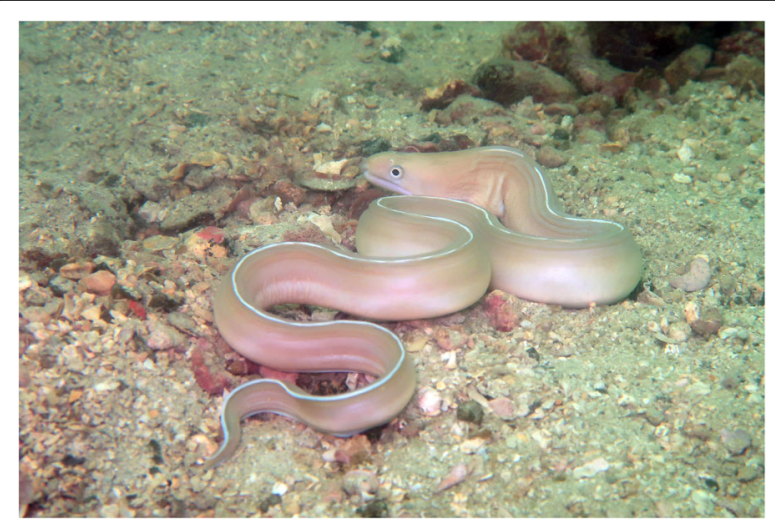

Fig. 13 An individual of Gymnothorax albimarginatus observed actively swimming and looking for shelter at Sharp Island 


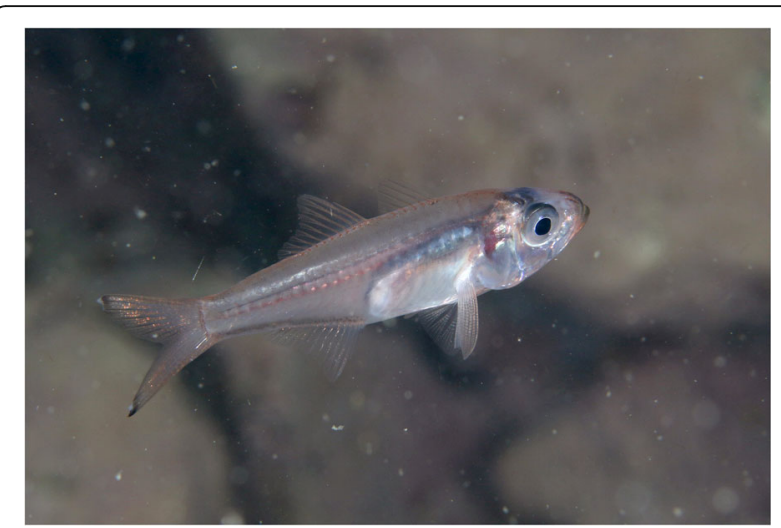

Fig. 14 An individual of Rhabdamia gracilis observed at night over rocky substrate at Clearwater Bay

Fiji, Marshall Islands, Micronesia, New Caledonia, Palau and Papua New Guinea (Fishbase 2018n; Liu 2008; Wu 2012).

\section{Echidna polyzona (Richardson, 1845) family: Muraenidae} An individual of Echidna polyzona (Richardson, 1845) was observed during night time at Clearwater Bay $\left(22^{\circ}\right.$ $16^{\prime} 19^{\prime \prime} \mathrm{N} ; 114^{\circ} 18^{\prime} 07^{\prime \prime} \mathrm{E}$ ) on 1 Jul 2018 (Fig. 15). The moray only protruded its head outside of the crevice at a rocky reef at about $6 \mathrm{~m}$ in depth. The size of the moray could not be easily noted as most of its body was hidden within the crevice, but it was likely to be about $60 \mathrm{~cm}$ in total length. This species is naturally found in the Indo-Pacific, covering about 41 counties/territories and territories, including India, Indonesia, Japan, mainland China, Philippines, Ryukyu Islands, Taiwan and Vietnam (Fishbase 2018o; Liu 2008; Wu 2012).

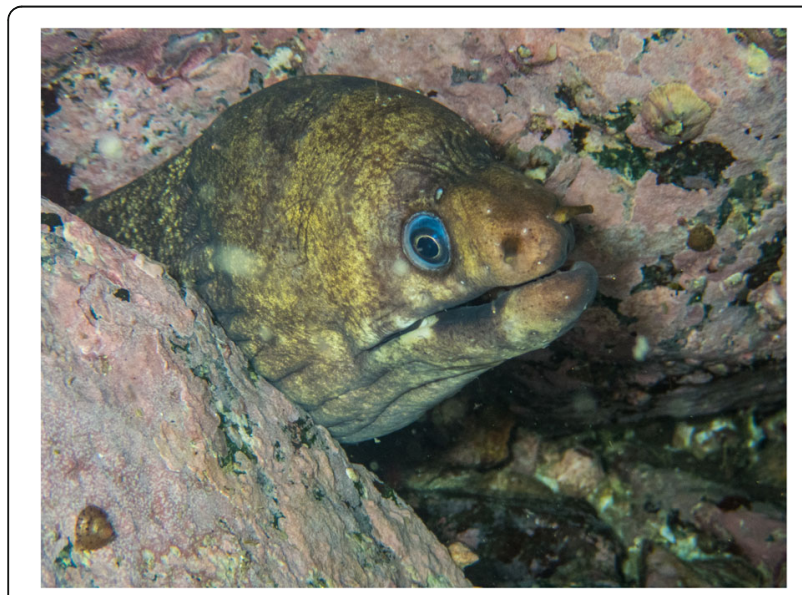

Fig. 15 An individual of Echidna polyzona spotted at night hiding within rocky reef at Clearwater Bay

\section{Naso unicornis (Forsskål, 1775) family: Acanthuridae}

An individual of Naso unicornis (Forsskål, 1775) was spotted in day time at Pak Lap Tsai $\left(22^{\circ} 21^{\prime} 112^{\prime \prime} \mathrm{N} ; 114^{\circ}\right.$ $\left.22^{\prime} 05^{\prime \prime} \mathrm{E}\right)$ swimming quickly near a rocky reef at about $2 \mathrm{~m}$ in depth on 7 Jul 2018 (Fig. 16). The individual, which was about $20 \mathrm{~cm}$ in fork length, was observed to actively swim away from the surveyor. Naso unicornis is found is in the Indo-Pacific covering about 59 countries and territories. These include India, Indonesia, Japan, mainland China, South Korea, Malaysia, Ogasawara Islands, Philippines, Ryukyu Islands, Taiwan and Vietnam (Fishbase 2018p; Liu 2008; Wu 2012).

\section{Discussion}

Applying the principle adapted in To and Shea (2016) to more reliably differentiate between naturally occurring and artificially introduced reef fish species in Hong Kong, all these 15 species reviewed are unlikely to be artificially introduced, due to the relative remoteness of the locations where these species were recorded. Generally, a potential reason for release would be that the fish outgrows the tank size in an aquarium; however almost all of the newly recorded species are relatively small in size. Notably, the individual of Gymnothorax albimarginatus was relatively large in size and was observed at Sharp Island, which is a site located close to residential areas and observed to be a popular area for 'mercy release' for a range of marine organisms, including fish. However, moray eel species are very unlikely to be used in mercy releases, and such release from aquarists is of low possibility, as this species is not observed to be popular in the aquarium trade (Chan and Sadovy 2000) and is not even observed to be available in the seafood market on a regular basis (Situ and Sadovy 2004).

Therefore these 15 species are unlikely to have been a result of release. In addition, all these 15 species have their native ranges covering sea areas of mainland China and Taiwan, with a few occurring in the South China

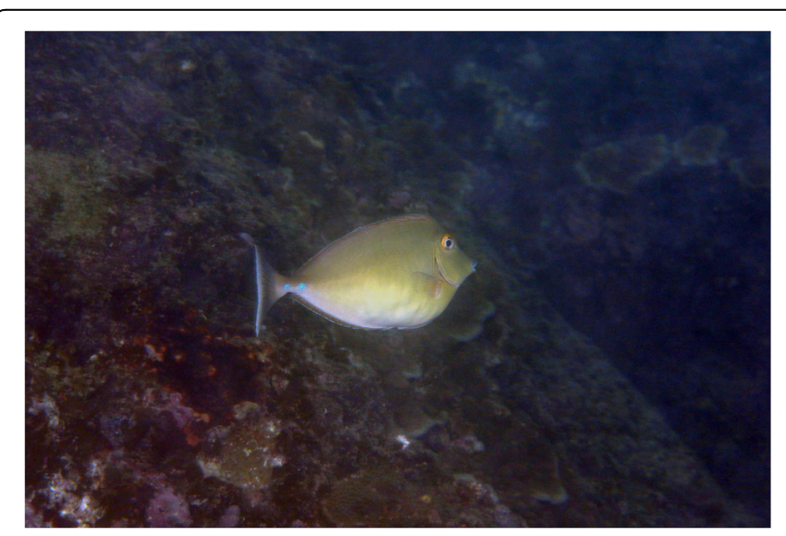

Fig. 16 An individual of Naso unicornis observed in day time near rocky reef at Pak Lap Tsai 
Sea region (Liu 2008; Wu 2012; Shao 2018). Their occurrence in Hong Kong therefore does not link to the species' native range extension and should be regarded as natural. As discussed by To and Shea (2016), the occurrence of new reef fish species records in Hong Kong might be explained by the pelagic status of eggs or fish at early stages of development for many reef fishes (Sadovy and Cornish 2000). Based on these limited observations for the species in this study, it is impossible to determine if these species can eventually establish to become a self-sustaining population in Hong Kong.

Notably, at least for a number of these newly recorded reef fish species, they may have already been in Hong Kong well before their formal documentation in this study, but were overlooked in the past for various reasons. For instance, the clingfish Pherallodus indicus is relatively small in size and often hides among sea urchins, which may have rendered it very easily overlooked by surveyors. The blenny Aspidontus taeniatus mimics the wrasse Labroides dimidiatus, and they share similar appearances. Although Labroides dimidiatus is not regarded as one of the most common reef fish species in Hong Kong (To and Shea 2017), it is relatively more well-known to divers due to its iconic cleaning behavior. For this reason, divers or surveyors in the past may have overlooked the presence of Aspidontus taeniatus or even wrongly assigned sightings of this species to Labroides dimidiatus. The same is also true for Chromis fumea, which shares close resemblance to the very commonly seen Chromis notata in Hong Kong (To and Shea 2017). The cryptic nature of some of the species, and close resemblance to some of the locally common fishes, might have rendered these species more difficult to be spotted, identified and recorded in past studies. It is therefore possible that some of these species have already been occurring in Hong Kong sporadically or might even have started to establish themselves towards more self-sustaining local populations.

\section{Conclusions}

This study confirms the occurrence of 15 new reef fish species to Hong Kong. The present findings hope to provide fundamental information on the local fish species for BSAP in Hong Kong, and to facilitate the accurate documentation of local species by updating the species list and distribution for reef fishes in Hong Kong waters.

\footnotetext{
Acknowledgements

The authors would like to thank Professor K.T. Shao (Biodiversity Research Center, Academia Sinica) and his team (particularly Chen Ching-Yi and Dr. Chen Hong-Ming), Dr. Andy Cornish (WWF) and Robert Myers (Seaclicks/Coral Graphics) for advice on species identification in this study. The authors would like to express deep gratitude to Kathleen $\mathrm{Ho}$ and Fion Cheung as dive buddies in this study and for their helpful comments during the preparation of this manuscript. Thank you to the Swire Group Charitable Trust for kindly
}

funding the expense of this publication and of dive surveys. The first author would furthermore like to thank ADM Capital Foundation for their unwavering support always. Immense gratitude is owed to all survey volunteers for their dedication to the project goal. Special thanks to Marco Chan, Andy Cornish, Andrew S.C. Fung, Eric Keung, Brian Lam, Calton Law, Teresa Ma, Gomen See, Ryan Tsang, and Caron Wong, who took the original photographs of new reef fish species reported in this study. Authors would also like to thank Diving Adventure, Scuba Monster and Ah Ming for providing logistic and technical support to conducting the dive surveys.

\section{Funding}

The Swire Group Charitable Trust provided financial support for the surveys in which the findings were made and for the expense of this publication. ADM Capital Foundation supported the survey project in kind by the provision of office space and office equipment.

\section{Availability of data and materials}

The dataset supporting the conclusions of this article is included within the article.

\section{Authors' contributions}

SKHS and AWLT are both involved in the field survey for reef fish in this study, and jointly identify species included in this study. Both prepared the draft of the manuscript and processed photos. Both authors read and approved the final manuscript.

Ethics approval and consent to participate

Not applicable.

Consent for publication

Not applicable.

\section{Competing interests}

The authors declare that they have no competing interests.

\section{Publisher's Note}

Springer Nature remains neutral with regard to jurisdictional claims in published maps and institutional affiliations.

\section{Author details}

${ }^{1}$ BLOOM Association, c/o, ADMCF, Suite 2405, 9 Queen's Road Central, Victoria, Hong Kong. ${ }^{2} 114^{\circ} \mathrm{E}$ Hong Kong Reef Fish Survey, C/o, ADMCF, Suite 2405, 9 Queen's Road Central, Victoria, Hong Kong. 'WWF-Hong Kong, 15/F, Manhattan Centre, 8 Kwai Cheong Road, Kwai Chung, New Territories, Hong Kong.

Received: 17 July 2018 Accepted: 12 October 2018

Published online: 06 November 2018

References

Allen GR, Erdmann MV. Reef fishes of the east indies volumes I-III. Perth: Tropical Reef Research; 2012.

Allen G, Steene R, Humann P, Deloach N. Reef fish identification tropical Pacific. 2nd ed. Florida: New World Publications; 2015.

CBD. 2018 CBD List of Parties. https://www.cbd.int/information/parties.shtml. Accessed date 30 Jun 2018

Chan TC, Sadovy Y. Profile of the marine aquarium fish trade in Hong Kong. Aquarium Sci Conserv. 2000;2(4):197-213.

Cornish AS. Fish assemblage associated with shall, fringing coral communities in sub-tropical Hong Kong: species composition, spatial and temporal patterns. PhD Thesis. Hong Kong: The University of Hong Kong; 1999.

Cotterill FPD. Systematics, biological knowledge and environmental conservation. Biodivers Conserv. 1995;4(2):183-205.

De Lacy T, Chapman J, Whitmore M, Worboys GL. Obtaining, managing and communicating information. In: Lockwood M, Worboys G, Kothari A, editors. Managing protected areas: a global guide. Trowbridge: Cornwell Press; 2006. p. 262-91.

Environment Bureau. Hong Kong biodiversity strategy and action plan 2016-2021. Hong Kong; 2016. https://www.afcd.gov.hk/tc_chi/conservation/ Con_hkbsap/files/HKBSAP_ENG_2.pdf. Accessed 24 Sept 2018. 
Fishbase. 2018a Chromis fumea. https:/www.fishbase.de/summary/Chromisfumea.html. Accessed 17 Aug 2018.

Fishbase. 2018b Pherallodus indicus. https://www.fishbase.de/summary/ Pherallodus-indicus.html. Accessed 17 Aug 2018.

Fishbase. 2018c Petroscirtes springeri. https://www.fishbase.de/summary/ Petroscirtes-springeri.html. Accessed 17 Aug 2018.

Fishbase. 2018d Myripristis botche. https://www.fishbase.de/summary/Myripristisbotche.html. Accessed 17 Aug 2018.

Fishbase. 2018e Valenciennea wardii. https://www.fishbase.de/summary/ Valenciennea-wardii.html. Accessed 17 Aug 2018.

Fishbase. $2018 \mathrm{f}$ Myripristis hexagona. https://www.fishbase.de/summary/ Myripristis-hexagona.html. Accessed 17 Aug 2018.

Fishbase. $2018 \mathrm{~g}$ Pseudanthias squamipinnis. https://www.fishbase.de/summary/ Pseudanthias-squamipinnis.html. Accessed 17 Aug 2018.

Fishbase. 2018h Xiphasis setifer. https://www.fishbase.de/summary/Xiphasiasetifer.html. Accessed 17 Aug 2018.

Fishbase. 2018i Cheilodipterus macrodon. https://www.fishbase.de/summary/ Cheilodipterus-macrodon.html. Accessed 17 Aug 2018.

Fishbase. 2018j. Cheilodipterus intermedius. https://www.fishbase.de/summary/ Cheilodipterus-intermedius.html. Accessed 17 Aug 2018.

Fishbase. 2018k. Aspidontus taeniatus. https://www.fishbase.de/summary/ Aspidontus-taeniatus.html. Accessed 17 Aug 2018.

Fishbase. 2018l. Tomiyamichthys oni. https://www.fishbase.de/summary/ Tomiyamichthys-oni.html. Accessed 17 Aug 2018.

Fishbase. 2018m. Gymnothorax albimarginatus. https:/www.fishbase.de/ summary/Gymnothorax-albimarginatus.html. Accessed 17 Aug 2018.

Fishbase. 2018n Rhabdamia gracilis. https://www.fishbase.de/summary/ Rhabdamia-gracilis.html. Accessed 17 Aug 2018.

Fishbase. 20180 Echidna polyzona. https://www.fishbase.de/summary/Echidnapolyzona.html. Accessed 17 Aug 2018.

Fishbase. 2018p Naso unicornis. https://www.ishbase.de/summary/Nasounicornis.html. Accessed 17 Aug 2018.

hk-fish.net. 2018 Hong Kong marine fish database. http://www.hk-fish.net/ english/marine_fauna_database/database_intro.html. Accessed 6 May 2018.

Kuwamura T. Reexamination on the aggressive mimicry of the cleaner wrasse Labroides dimidiatus by the blenny Aspidontus taeniatus (Pisces; Perciformes). J Ethol. 1983;1:22-33.

Liu J. Subpylum vertebrata Cuvier, 1812. In: Liu R, editor. Checklist of marine biota of China seas. Beijing: China Science Publishing \& Media Ltd; 2008. p. 886-1066.

Ng TPT, Cheng MCF, Ho KKY, Lui GCS, Leung KMY, Williams GA. Hong Kong's rich marine biodiversity: the unseen wealth of South China's megalopolis. Biodivers Conserv. 2017;26(1):23-36.

$\mathrm{Ni}$ I, Kwok K. Marine fish fauna in Hong Kong water. Zool Stud. 1999;38:130-52.

Sadovy Y, Cornish AS. Reef fishes of Hong Kong. Hong Kong: Hong Kong University Press; 2000

Sadovy Y. Reef fish diversity in Hong Kong. Procupine. 2001 https://www.biosch. hku.hk/ecology/porcupine/por22/22-cover-ys.htm Accessed 24 Sept 2018.

Shao KT. 2018 Taiwan fish database. http://fishdb.sinica.edu.tw. Accessed 7 May 2018.

Situ YY, Sadovy YJ. A preliminary study on local species diversity and seasonal composition in a Hong Kong wet market. Asian Fish Sci. 2004;17:235-48.

To AWL, Shea SKH. New records of four reef fish species for Hong Kong. Mar Biodivers Rec. 2016;9:82

To A, Ching K, Shea S. Hong Kong reef fish photo guide. Hong Kong: EcoEducation and Resources Centre; 2013.

To AWL, Shea SKH. Field guide to common reef fishes of Hong Kong. Hong Kong: Agriculture, Fisheries and Conservation Department; 2017.

Wu H. Vertebrata. In: Huang Z, Lin M, editors. The living species and their illustrations in China's seas (part I) the living species in China's seas. Beijing: China Ocean Press; 2012. p. 919-1160.

Ready to submit your research? Choose BMC and benefit from:

- fast, convenient online submission

- thorough peer review by experienced researchers in your field

- rapid publication on acceptance

- support for research data, including large and complex data types

- gold Open Access which fosters wider collaboration and increased citations

- maximum visibility for your research: over $100 \mathrm{M}$ website views per year

At BMC, research is always in progress.

Learn more biomedcentral.com/submissions 